\section{Glasnost not fully practised}

\section{London}

Despite official Soviet encouragement of glasnost, general implementation of the policy remains haphazard. Although some 90 per cent of the stocks of foreign periodicals in Soviet libraries have now been transferred to open access (to the chagrin of librarians who have thus lost their bonuses for dealing with classified material), some 40 per cent of Soviet periodicals have been subjected to a quota system arising from what is described officially as a lack of newsprint

The periodicals whose subscriptions for 1989 will be restricted include many that have played a prominent part in recent disclosures in the Soviet press. Part of the official explanation is that a number of pulp mills have been closed on environmental grounds.

A more serious problem is the habit of secrecy engrained in Soviet enterprises, in which the space programme is especially culpable according to Pravda's science correspondent, A. Pokrovski. While medals and awards are no longer conferred in secret, the space planners remain unnecessarily security-conscious.

Pokrovski says that Soviet hopes of earning hard currency by launching foreign satellites have been thwarted because Western insurers cannot obtain data on the reliability of Soviet launchers. Industrial spin-off from the space programme is rare, he writes, despite official assurances that space research is meant to benefit the national economy.

New pieces of space hardware described in Pravda are said to evoke floods of letters asking when the new pump, alloy or medical monitoring device will be generally available - but in vain. Photographs and telemetry images from space similarly fail to reach the agricultural or forestry experts who could use them, although similar materials are available — at a price - for almost any region of the world, from space agencies less obsessed with secrecy.

The Soviet Union's partners in space do not share this caution. Czechoslovakia, not normally regarded as being at the forefront of glasnost, has allowed the lasers developed by the Czech Technical University for the Interkosmos ranging programme to be adapted for surgical use.

Only in cartography is there a breakthrough in the use of Soviet space surveys. New maps have been promised which, for the first time since 1917 , will reflect the genuine contours of Soviet cities. They will, presumably, also correct deliberate errors in the latitude and longitude of major cities, which historian Roy Medvedev has reported.

\title{
French research budget increase may have long-term drawbacks
}

Paris

AN INCREASE of 7.6 per cent in the French civil research and development budget for 1989, announced at the beginning of August (see Nature 334, 556; 1988) has now been given government approval. In the short term, the budget will lift morale in public sector research, giving French science and technology a boost in the runup to a free-market Europe in 1992. But this state investment depends on receipts from France's highly idiosyncratic tax structure, which may have to be revised if plans to implement a common European taxation system in 1993 are upheld.

President François Mitterrand promised, in his spring electoral campaign, to make research and education a national priority and so this budget comes as no surprise. While tax incentives for industrial research, initially established under the socialists but greatly extended under the Chirac government, remain untouched, Prime Minister Michel Rocard shares Mitterrand's faith in the public sector.

Between 1966 and 1988, civil research spending dropped by 3.7 per cent and recruitment was effectively halted. Much of the current increase in spending is aimed at redressing this net downward trend. This year, 597 new research posts and 316 engineer and technician positions have been created, compared to 150 research and no technician posts in 1988.
The technology development agency ANVAR receives a 15 per cent increase in grants.

But where is the money coming from to pay for these increases? This generosity with the public purse is bold, given that Mitterrand has also promised to reduce the national debt, just as the full cost of France's enthusiastic engagement in the European space programme will start to be felt. Evidently, some cuts have been made. Grants to industry as a whole have dropped by 0.62 per cent, whereas the atomic energy commission (CEA) receives 5.2 per cent less than last year and almost 6,000 defence jobs are to be lost.

Overall, Rocard's 1989 budget is more than covered by an increase in France's gross domestic product (5.1 per cent). Tax receipts, particularly from value-added tax on goods and services, are also up on last year. And it is this revenue which largely supports the current expansion in public sector spending. But French taxation is out of step with almost every other European country. Value-added tax is high (an average of 19.9 per cent compared to 15.9 per cent in Britain), whereas income tax is low (an average of 12.7 per cent). If European nations push ahead with plans to introduce a uniform tax structure in 1993, the French economy will be faced with severe problems of adjustment.

Peter Coles

\section{More money needed to beat pollution}

\section{Washington}

ADMINISTRATORS at the US Environmental Protection Agency (EPA) have unveiled plans to bolster basic research on the prevention and reduction of environmental pollutants. The plans would double the agency's research budget and shift its focus from monitoring and cleaning up pollution at the "end of the pipeline" to the development of strategies for reducing the amount of pollution created in the first place.

The plans were drawn up at the request of EPA administrator Lee Thomas by a committee composed of members of the agency's Science Advisory Board, the governmental equivalent of a corporate board of directors. Thomas asked the committee to advise on the direction the agency should take over the long-term, given that the sources of pollution are becoming increasingly decentralized and that disposal sites for hazardous materials are quickly being exhausted.

The committee concluded that regulating industrial emissions and waste is no longer sufficient, and that the EPA should take a larger role in promoting research into ways to reduce the amount of pollutants being produced. The committee's ten recommendations centre on reorganizing the EPA administration to give more prominence to long-term research.

Specifically, the committee suggested creating an Environmental Research Institute to lead a national programme of ecological research, setting up a council to define core research areas, and changing the EPA Assistant Administrator for Research and Development from a political to a career position.

To pay for the changes, the committee recommends that EPA's \$317 million research budget be doubled over the next 5 years. While such an increase may seem extravagant, the committee says that the sum is small compared with the $\$ 70,000$ million the United States now spends on pollution control each year. But the Reagan administration is winding down, and the fate of the plans depends on who is appointed head of the EPA by the next occupant of the White House. Carol Ezzell 